\title{
Characterization of Basement Fracture Reservoir In Field 'X', South Sumatera Basin, Based On The Analysis of Core And FMI Log
}

\author{
Hartawi Riskha ${ }^{1} *$, Ildrem Syafri ${ }^{1}$, Ismawan $^{1}$, and Nanda Natasia ${ }^{1}$ \\ ${ }^{1}$ Faculty of Geological Engineering, Universitas Padjadjaran, Jl.Raya Bandung - Sumedang Km.21 Jatinangor
}

\begin{abstract}
* Corresponding author : hartawi.riskha@gmail.com
Tel : +62823-8851-4515

Received: Apr 3, 2017. Revised : May 10 2017, Accepted: May 25, 2017, Published: 1 June 2017

DOI: 10.24273/jgeet.2017.2.2.196

Abstract

Basement reservoir is a reservoir that is located at the basement rock, comprised of either igneous rock or metamorphic rock that has secondary porosity, resulting in its capability to store oil and gas. The research was conducted at field ' $X$ ' that is located at South Sumatra basin and it is a part of Jambi Sub-Basin. The study was focused to discuss hydrocarbon potential in Fields 'X', particularly at the basement metamorphic rock. The study was conducted at two wells in the field. The secondary porosity system of the basement is fracture porosity. Fracture analysis as secondary porosity system was performed on two wells, HA-1 and HA-2, by using FMI log interpretation. Based on the analysis of fracture on HA- 1 well, the trend of fracture system is Northeast - Southwest (NE-SW) with a fracture porosityof $1.49 \%$ On a different note, the trend of fracture system on HA-2 wells is East Northeast - West Southwest (ENE-WSW) with a fracture porosity of $0.888 \%$ The effect of rock properties itself has little influence on the number of fractures as opposed to the effect of surrounding tectonic forces. The fractures is controlled by geological structures following Jambi pattern that has an orientation of Northeast - Southwest (NE-SW). Although the fracture porosity is relatively small, it is enough to storing hydrocarbons in economical quantity.
\end{abstract}

Keywords: Basement, FMI log, fracture porosity, Jambi Pattern

\section{Introduction}

Basement reservoir is a reservoir that is located at the basement rock, comprised of igneous rock or metamorphic rock that has secondary porosity thus resulting in its capability to store crudeoil and natural gas (Landes, K.K, 1960) (Aguiera, L, 1995). Fractured basement reservoir quality depends on several factors such as structural type, lithology, stress character, basement relief, and many other which will affect the reservoir porosity. Crystalline rock reservoir is formed as a result of tectonic forces which cause the surrounding area to get uplifted and weathered before another layer of sedimentary rock from different and younger age was deposited on top of it.

Field "X" is a part of South Sumatra basin with an approximate area of $9653 \mathrm{~km} 2$ (Indonesian Basin Summaries, 2006). This study was focused to discuss hydrocarbon potential in field " $X$ ". In this study, the discussion was conducted on PreTertiary Metasediment formation, also known asbasement formation or basementrock. This was based on the goal of this research which is to determine the characteristics of basement reservoir. The research at field " $X$ " was also based on the availability of data in the form of core and FMI log data.
Location of the research in South Sumatera Basin, especially in Jambi sub-Basin (Fig. 1). Jambi Sub-Basin is part of South Sumatera Basin. The location of the research area is in part of the muarobungo regional geological map, jambi, sarolangun, and Palembang regional geological map.

\section{Regional Geology of South Sumatra Basin}

The South Sumatra basin is a product of tectonic process in the form of Indo-Australian plate subduction, which shifted north to northeast against the relatively static Eurasian plate. subduction. The subduction zone includes the western area of Sumatra and Java. The direction of the aforementioned subduction affected the condition of rocks, morphology, tectonic, and structure of South Sumatra.

The collision of tectonic plate at Sumatra produced magmatic forearc and back-arc pathways. The South Sumatra basin is a back-arc basin that was formed as a result of a depression which was surrounded by Pre-Tertiary mountain ranges.

\subsection{Stratigraphy of South Sumatra Basin}

The site of the research is located at Jambi subbasin. Meanwhile, the stratigraphy of the site is as follows: 


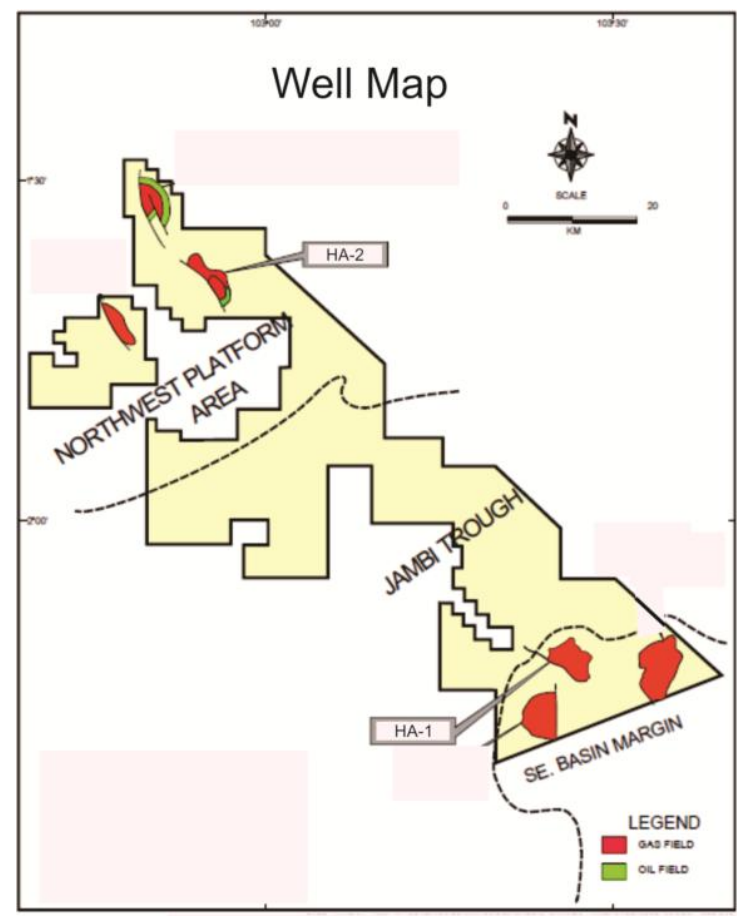

Fig. 1. Location of Research Area

\section{Pre-Tertiary basement (BSM)}

Basement rock of SouthSumatra and Central Sumatra is a Pre-Tertiary complex that is comprised of Mesozoic rocks and Paleozoic Mesozoic metamorphic rocks. According to result of radiometric dating, this basement rock was formed during the Late Cretaceous period and up to Paleocene - Eocene epoch (Bishop, 2001).

\section{Lahat Formation (LAF)}

This formation was deposited on top of basement rock, and it is also referred to as Lemat Formation (De Coster, 1974). This formation is comprised of sandstones, mudstones, rock fragments, breccias, coal seams, and tuffs, all of which were deposited on terrestrial environtments.

\section{Talang Akar Formation (TAF)}

Talang Akar Formation was deposited noncontinuously on top of Lemat/Lahat formation, but if Lahat Formation was proven to be undeveloped, it can be concluded that this formation was deposited continuously on top of Pre-Tertiary basement rock. Talang Akar formation was formed during the Late Oligocene - Early M iocene epoch. Identified specific sedimentary environtments are open seas, shallow waters, river deltas, distributary channels, fluvial, and beach (Hutapea, 1981 in Bishop, 2001).

\section{Baturaja Formation (BRF)}

This formation was deposited continuously on top of Talang Akar formation and it is comprised of limestones. The build-up on the formation is associated with carbonate platform. It has massive property, coral and algae boundstones on top of foraminifera greenstones, weakstoes, packstones and marls. The facies indicates the presences of open reef shoal, fore reef, dan back reef sediments. Gumai Formation (GUF)

This formation was deposited after Baturaja formation and it is a product of sedimentary deposition when the tidal wave reached its peak.This formation is comprised of tuffaceous marl with either light or dark gray color. In some cases, layers of glauconite sandstones, tuffs, tuffaceous breccias, shales and limestones can be found in this formation.

\section{Air Benakat Formation}

This formation is the early stage of Palembang group deposition cycle, which occured during the deposition of low tide sediment. This formation was formed during the Late Miocene - Pliocene epoch. Its lithology is comprised of tuffaceous sandstones, some tuffaceuous muds that were intertwined with marlstones or sandstones that has its glauconite composition continue to decrease as it goes up.

\section{Muara Enim Formation (MEF)}

This formation was deposited on top of Benakat Air formaton. This formation can be divided into two members: Member "a" and member "b". Member "a" is also referred to as Brown Member which is comprised of mudstones, brown to grayish brown sandstones, and fine-grained to medium grained sandstones. In Palembang area, there's also coal seams. Member " $b$ " is also refererred to as Blue Green Member and it's comprised of sandy mudstone and tuffaceous mudstone with white and light gray color.

\section{Kasai Formation (KAF)}

This formation marks the end of low tide sediment cycle (De Coster dan Adiwijaya, 1973). The lower part is comprised of tuffaceous sandstones with some tuffaceous mudstones mixed in between layers, conglomerates and tuffaceous mudstones that were intertwined with each other, and loose mudstones. Meanwhile, the upper part is comprised of pumices which contained silicified woods that formed cross sedimentary structure, lignites that were deposited as lenticular bedding within sandstones and tuffaceous mudstones.

\section{Basement rock}

According to Landes et al (1960), basement rock is defined asmetamorphic or igneous rock (regardless of its age) that were deposited noncontinuously on top of a sedimentary rock sequence. Later on, Aguilera (1995) stated that sandstones and carboniferous rocks are not considered as basement rocks, even though those rocks were buried below the rock formation which serves as source rock.

\section{Basement Reservoir}

Basement reservoir that has experienced fracture is a part of the reservoir that has experienced natural fracture process, whether it's from metamorphic or igneous rock (regardless of its age) where a sedimentary sequence was deposited non continuously on top of it (Landes et 
al., 1960). The fractures may originate from tectonic process or weathering process. Several factors that might influence the fracture on a formation are lithology, structure, history of uplift and depression, diagenesis, main stress, and fluid pressure.

\subsection{Tectonic of South Sumatra Basin}

South Sumatra basin has experienced three orogeny processes, with the first one occured during the Middle Mesozoic period, the second one occured during the Late Crectaceous - Early Tertiary period while the third one occured during the Pliocene - Pleistocene epoch (Hamilton, 1979) (Pulunggono, A. et al 1992) (Simadjuntak, T.O, 2015). The tectonic and geological structure of South Sumatra basin area can be separated into two group, which are as follows:

Semangko Fault Zone, northwest - southeast oriented Fold Zone (Diament, 1992), and Fault Zones that are associated with folds and PreTertiary faults (Handayani, L, 2008). During the Mesozoic tectonic episode,deposited rocks were uplifted, undergone metamorphism process, folded, and separated by faults into a complex zone and formed the frame structure of Sumatra island. These rocks were outcropped and formed Barisan Mountains. During the Late Cretaceous - Early Tertiary episode, there's a tensile stress which occured in the region and formed grabens, faults, and fault blocks with north - south or northwest southeast orientation with the remaining blocks having northeast and northwest orientation.

The Early Tertiary - Miocene episode is marked by basin subsidence and the deposition of tertiary sediments. Calcarenite sediments were starting to develop from Baturaja limestone. During the early Miocene, the transgression phase was replaced by regression phase as indicated by the deposition of sediments from Air Benakat formation (Middle Miocene - Late Miocene) dan lake sediments from Muara Enim formation (Late Miocene - Pliocene) (Pulunggono, A. et al 1992) (Simadjuntak, T.O, 2015).

The Pliocene - Pleistocene tectonic episode is marked by northwest oriented folds and faults. The compression of Pliocene - Pleistocene formed the current structural configuration. During that time, there's an overturn on several parts of the basin, while the volcanic materials of Kasai Tuff formation were deposited simultaneously on the lower parts. The fold zone is a product of Pliocene - Pleistocene orogeny tectonic process which formed multiple northeast - southwest oriented anticlines and synclines that are aligned with the major axis of Sumatra island. This tectonic pattern caused the South Sumatra basin to form asymmetrically (Pulunggono, A. et al 1992) (Simadjuntak, T.O, 2015).

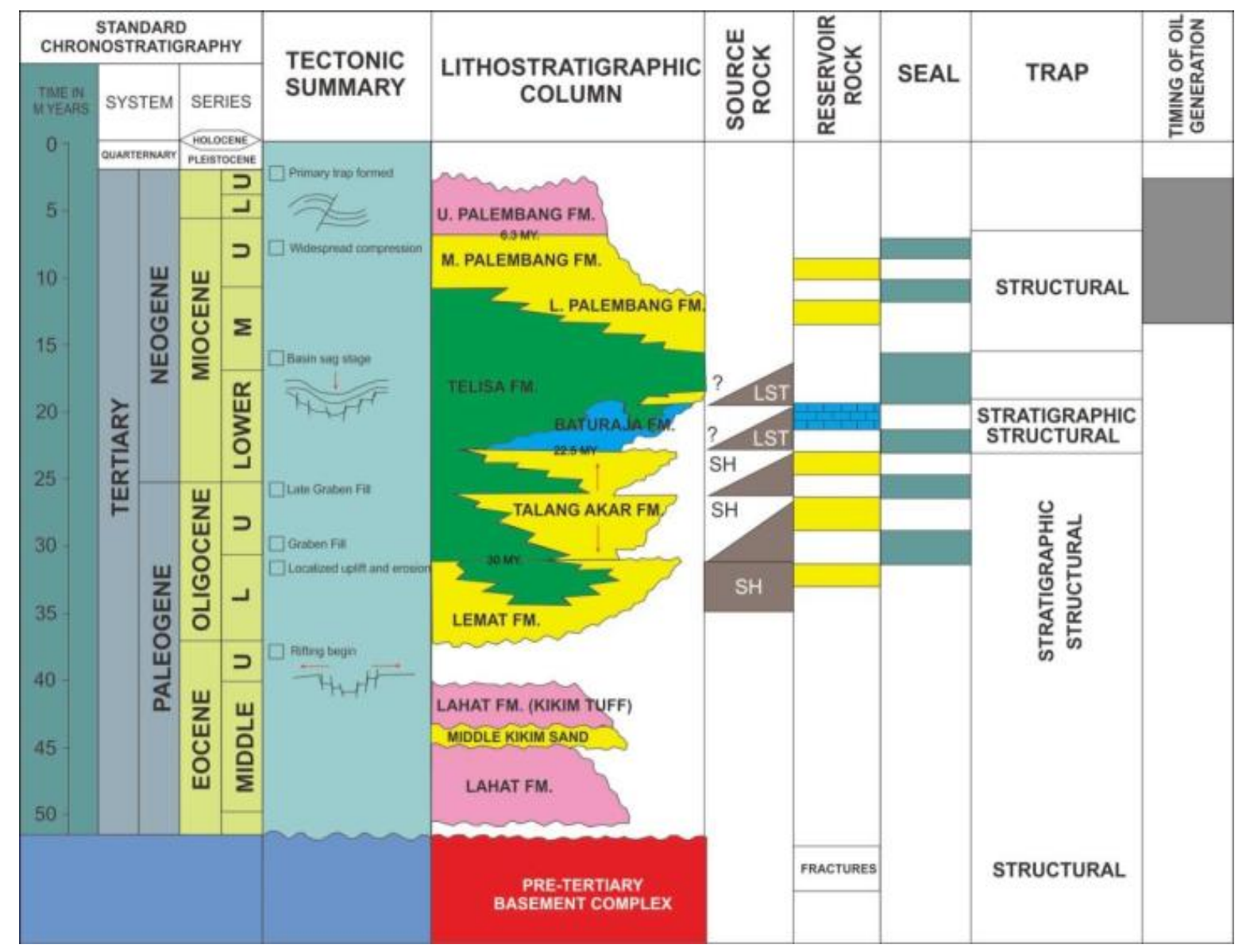

Fig. 2. Stratigraphy Column of South Sumatra Basin (De Coster, 1974) 


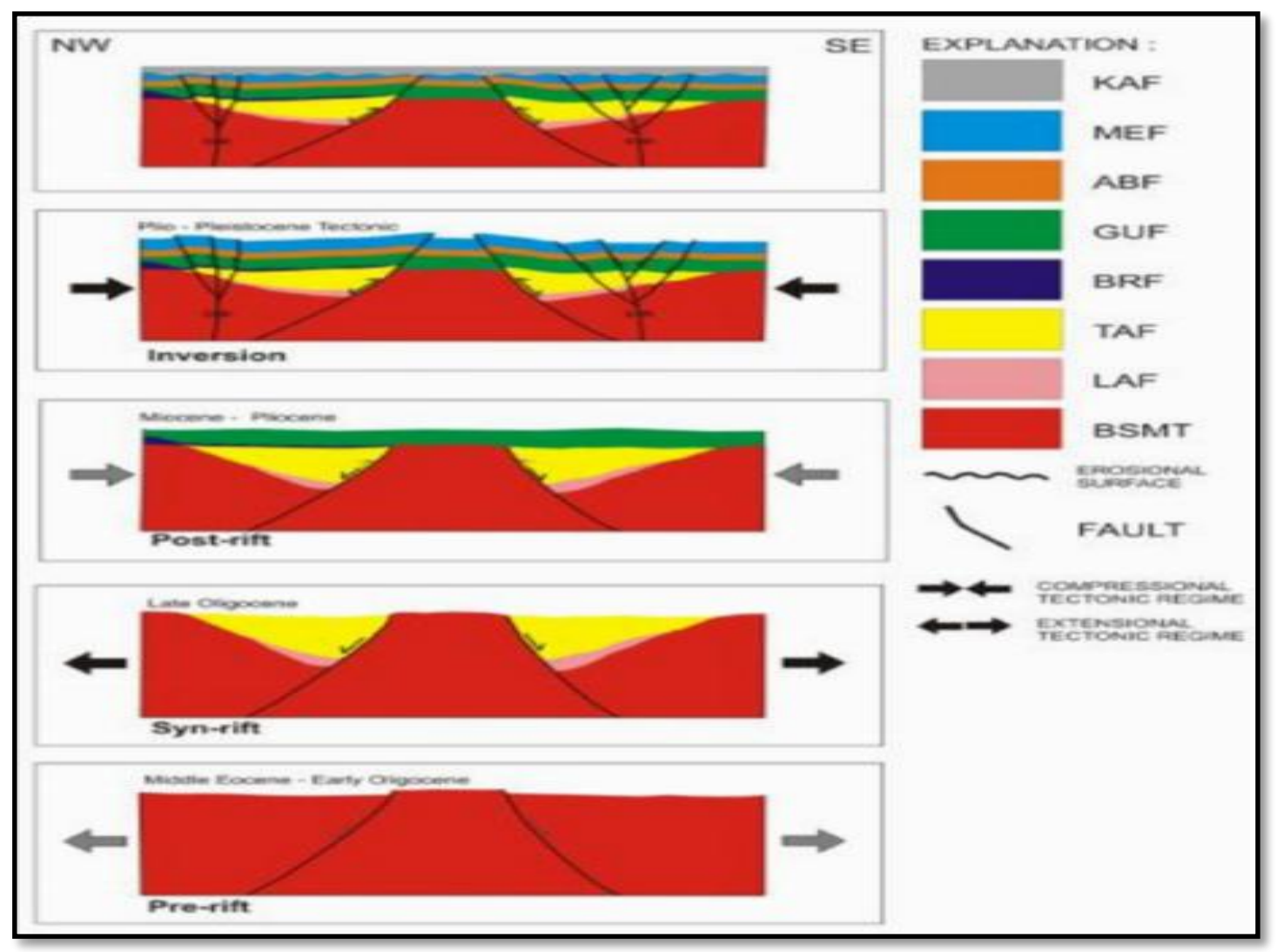

Fig. 2. Development of Major Basin Configuring Tectonics (De Coster, 1974)

\section{Data and Methodology}

Data for this research conducted on two wells, namely $\mathrm{HA}-1$ and $\mathrm{HA}-2$ with low resistivity metamorphic rock as the lithology. The analysis for this research are using several method, as follow:

(1) Petrography Analysis, the analysis was conducted to determine the lithology and composition of minerals within the rock. Blue dye epoxy resin was dropped to the thin section in order to differentiate between genuine pores and artificial holes due to imperfect preparation process. This method will greatly contribute in identifying fracture on thin section (Raymond, L.A, 1943) (Sen, G., 2001) (Syafri, I, 2002). (2) Fracture Picking, As secondary porosity, it is known that not all fractures may serve as a vessel to store fluid. Only certain fracture may act as secondary porosity, namely open fracture.As such, fracturepicking is used to determine types of any presence fracture, because open fracture is the only type of fracture that can serve as secondary porosity. Each type of fracture and bedding showed different appearances on log images. Open fracture has dark shade which form sinusoidal pattern and conductive property because it's filled with drilling mud. Meanwhile, crosed fracture has lighter shade which form sinusoidal pattern, in contrast with its surrounding, and has resistive property because it's filled with semen or other minerals thus forming veins.Bedding has a similar dark shade as open fracture but with a more level sinusoidal pattern because its low dip value. Furthermore, there's an induced fracture or fracture that was made artificially during the coring process, drilling, fluid injection, etc. The appearance on log images tend to not possess any orientation. (3) Fracture density, this analysis needs to be determined in order to know how many fractures within a certain scale (Nelson R.A, 2001). In this research, the fracture density scale was set at 1 meter.The density of fracture was focused on open fractures, mainly because these fractures are the ones which will later become secondary porosity.

The equation to measure fracture density is as follows:

$$
\begin{aligned}
& \text { fracture density }=\frac{\mathrm{n}}{\mathrm{M}} \\
& \qquad \begin{array}{l}
\text { with: } \\
\mathrm{n}=\text { the number of fractures } \\
\mathrm{M}=\text { meter }
\end{array}
\end{aligned}
$$

(4) Fracture Aperture, this analysis will determine the porosity value of fracture. The determination of aperture value can only be done through the use of certain instrument. And (5) Fracture Porosity, Fracture porosityis a porosity that was formed due to a fracture.The size of fracture porosity is affected by the number of fractures and the size of apertures. Determining the fracture porosity is essential in order to know the quality of the fracture to store fluid.

Secondary porosity index (SPI) from sonic log and density log may help in analyzing fracture 
porosity.The SPI itself is a measure of secondary porosity that is associated with fracture and/or vuggy (Asquith, 1976) (Koesoemadinata, R.P 2000) (Rider, M , 2001) (Zou, C, 2013). The determination of SPI can be helpful in determining fracture from log images. The following equation is used to cal culate SPI:

SPI $=\Phi$ density $-\Phi$ sonic

with:

SPI : Secondary Porosity Index

$\Phi$ density : : Porosity from log density

$\Phi$ sonic : : Porosity from log sonic

Basically, determining the fracture type during fracture picking will produce better result if it's done by the proper interpretation concept on log images and the validation of supporting data utilized several available parameters, one which is the SPI value.The obtained values will help in detecting the presence of fractures at a certain depth. Although it's not too accurate, this process is enough as validation data in order to determine fracture. High SPI value will indicate the presence of fractures at a certain depth.

The value of fracture porosity is determined from the size of aperture and the number of fracture (fracture density). The following equation is used to calculate fracture porosity:

$\Phi f=\frac{\mathrm{e}}{\mathrm{D}+\mathrm{e}} \times 100 \%$

with:

Фf : : Fracture porosity

e : : Average effective aperture size

D : : Average space between aperture

\section{Result}

Analysis was conducted on basement formation or basement rock on two wells, namely HA-1 (Fig. 5.) and HA-2 (Fig.6.) with low resistivity metamorphic rock as the lithology. HA-1 well is comprised of marble, slate, phyllite, and quartzite. Meanwhile, HA-2 well is comprised of slate, phyllite, schist, and quartzite.

This rock is comprised of $69.9 \%$ component, $3.2 \%$ matrix, $25.6 \%$ fracture fill, and $1.6 \%$ visible porosity. The component of this rock is comprised of $4 \%$ quartz, $1.2 \%$ mica, $40.4 \%$ carbonate from re- crystallization process, and $24.0 \%$ dolomite.The matrix of this rock is comprised of $3.2 \%$ mudstone matrix. The fracture fill is comprised of 0.4\% kaolinite mineral, 5.6\% quartz, $4.0 \%$ dolomite, $4.0 \%$ ferroan dolomit, $7.6 \%$ calcite, $1.6 \%$ ferroan calsite, and $2.4 \%$ opaque mineral in the form of pyrite.

Structure that identified from the thin Section A: stylolites (sty), trace of possible bedding (lam), kalsit (FRc), ferroan kalsit (FRcf), pyrite (Frpy), kaolinite (FRk). On thin section B: There's two fracture, with the first one being vertical fracture filled with ferroan dolomite (FRdf) and replaced by ferroan kalsit (FRcf).

Fracture picking that conducted on two wells, resulting that on well HA-1 (Fig 4.), the log image data are only present on 100 meters interval vertically. This is due to thelimited amount of data. But the data on well HA-1 is enough to represent the fracture condition on all interval of this well basement. 447 fractures were identified on well HA-1 (Fig .7.), with 289 of them are open fractures. Meanwhile on well HA-2 (Fig.7.), the log image data are present on all interval of basement rock. 956 fractures were identified on this well, with 592 of them are open fractures. Aside from open fracture, there's alsoclosed fracture.This closed fracture is usually filed with minerals from mineralization process, such as calcite or secondary quartz, which later on becomes vein.This occurence is visible during the petrography analysis on rock samples with the presence of minerals in the fractures. Although genetically speaking, open fracture and closed fracture are similar because they are formed from extensional stress. Some of the resulting open fractures will be filled with minerals, causing them to 'close', hence the name.

Fracture density analysis that resulting using the eq 2. Resulting Well HA-1 has an average fracture density of $0.831 / \mathrm{M}$ (Fig. 7.) while HA-2 has an average fracture density of $0.778 / \mathrm{M}$ (Fig.8.). The fracture intensity of well HA-2 varies with each interval. This showed us that the present fractures are not affected by the rock properties to a significant degree.

Fracture porosity value determined by using eq. 3. HA-1 has an average fracture porosity value of $1.49 \%$ while $\mathrm{HA}-2$ has an average fracture porosity value of $0.888 \%$
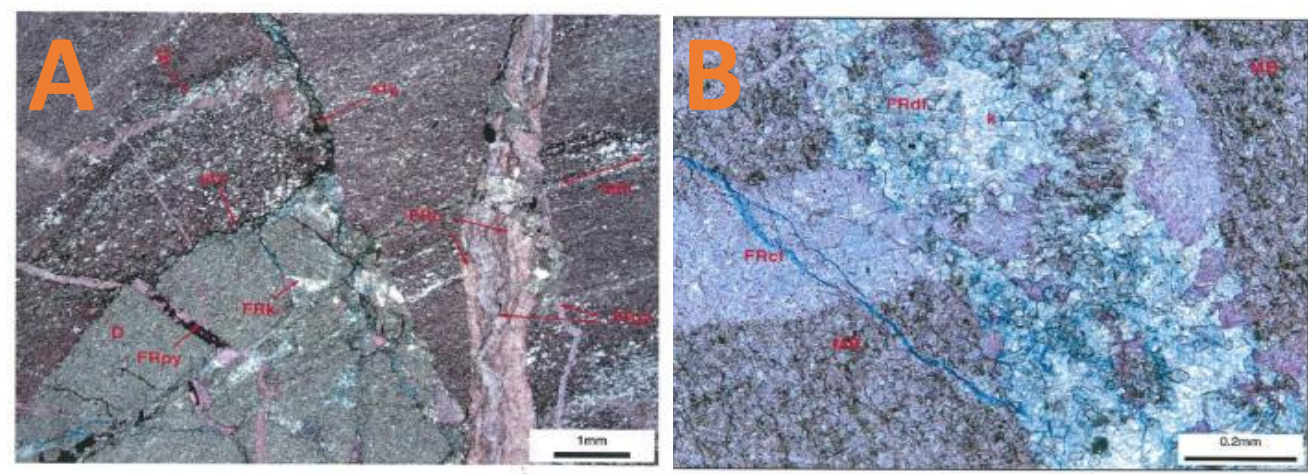
Fig. 3. Thin Section of Well HA - 1 and HA-2.

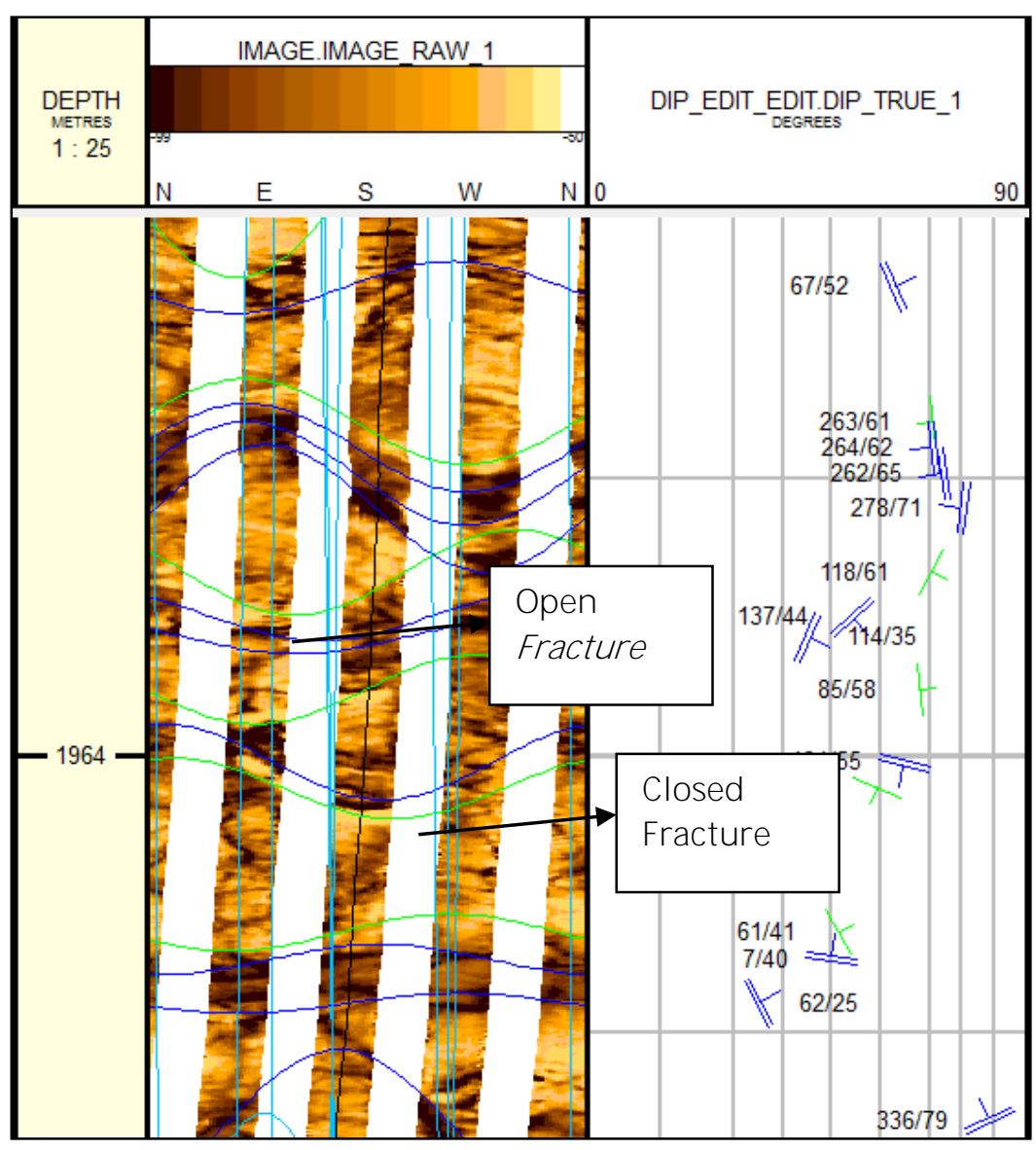

Fig. 4. Fracture picking from log images on well HA-2

Table 1. Analysis Petrography Composition of Mineral

\begin{tabular}{llc}
\hline Compositon & Mineral & V (\%) \\
\hline \multirow{4}{*}{ Framework Grains } & Quartz & 4 \\
& Mica & 1.2 \\
& Matrix Block Carbonate (Recrystallized) & 40.3 \\
& Dolomite-replaced grains & 24 \\
\hline & Kaolinite & 0.4 \\
& Authigenic quartz & 5.6 \\
& Dolomite & 4 \\
Fracture Fills / Replacement & Ferroan Dolomite & 4 \\
& Calcite & 7.6 \\
& Ferroan Calcite & 1.6 \\
& Pyrite / Opaques & 2.4 \\
\hline Matrix & Clay Matrix & 3.2 \\
\hline Visible Porosity & Porosity-undifferentiated & 1.6 \\
\hline
\end{tabular}



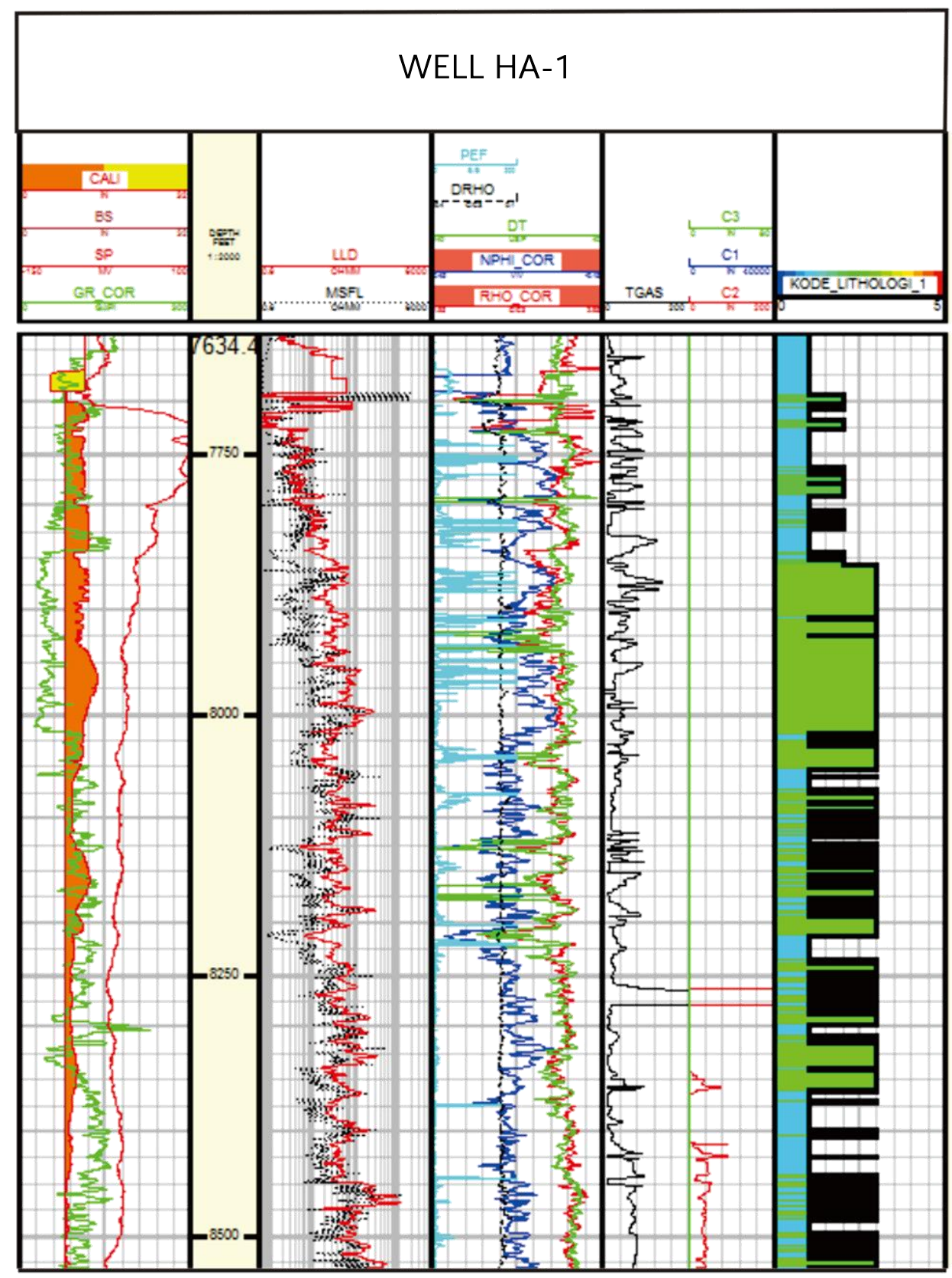

Explanation

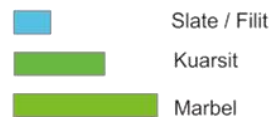

Fig 5. Log graphic of well HA-1 


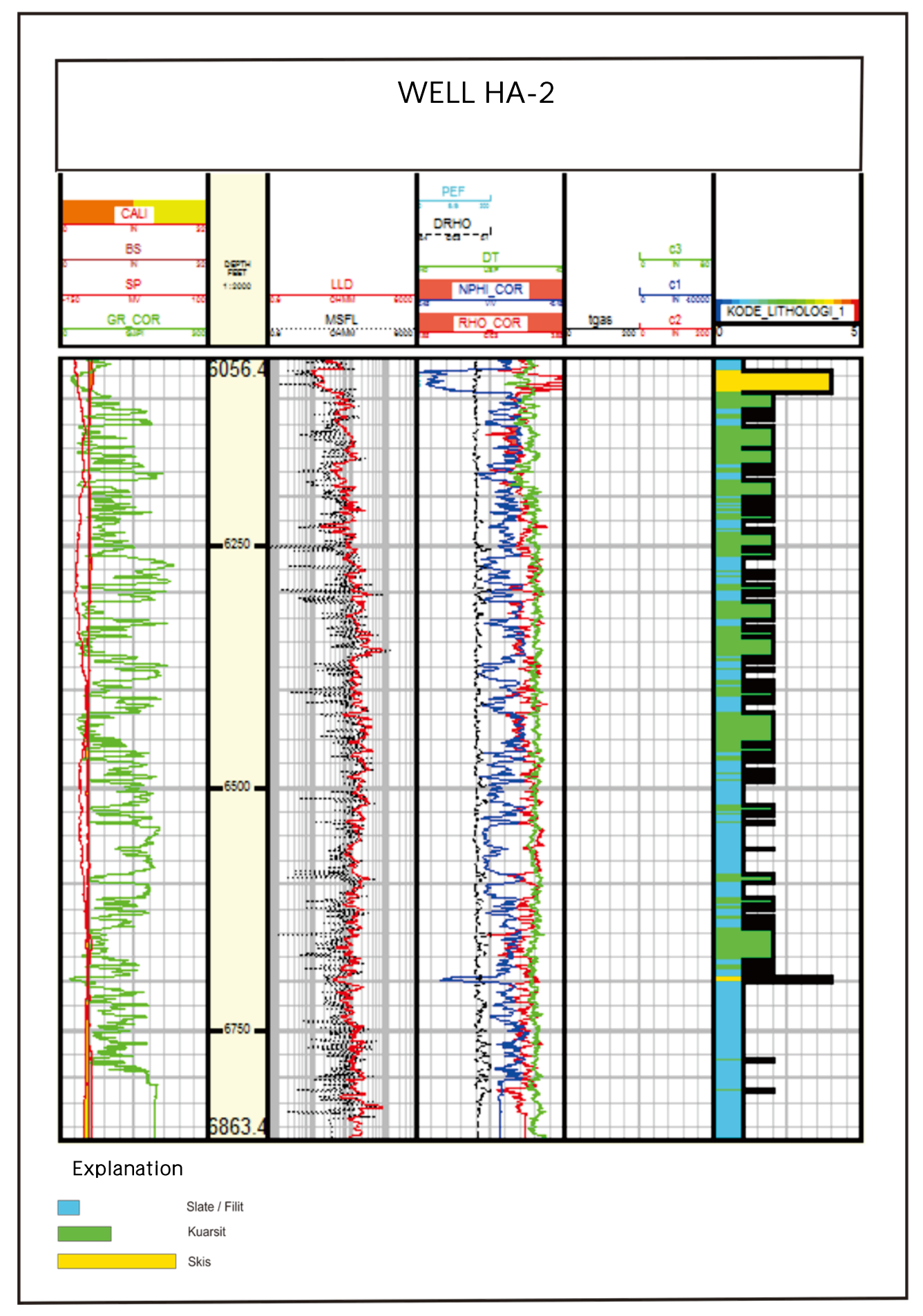

Fig 6. Log graphic of well HA-2 


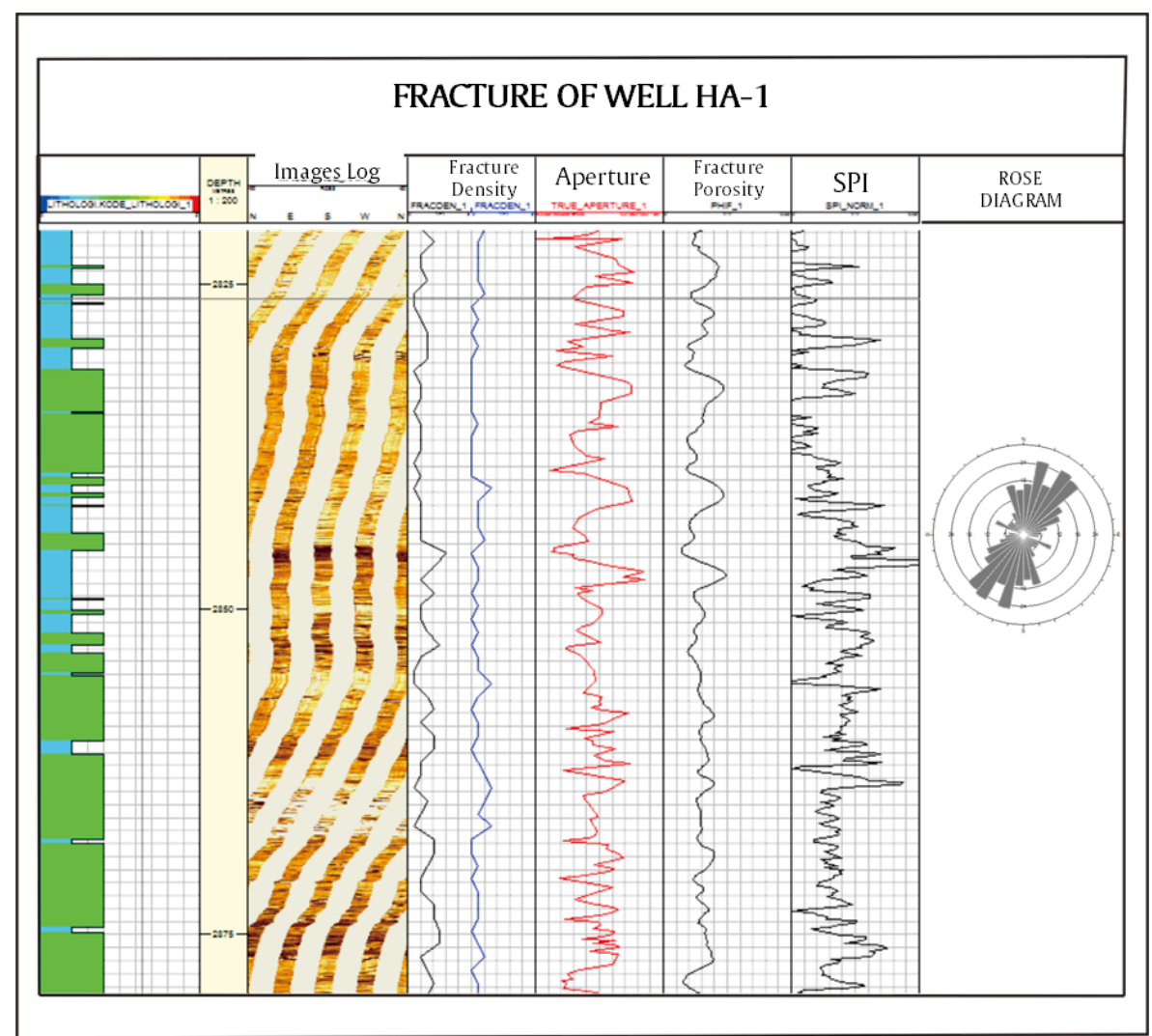

Fig. 7. Fracture from log images on well HA-1

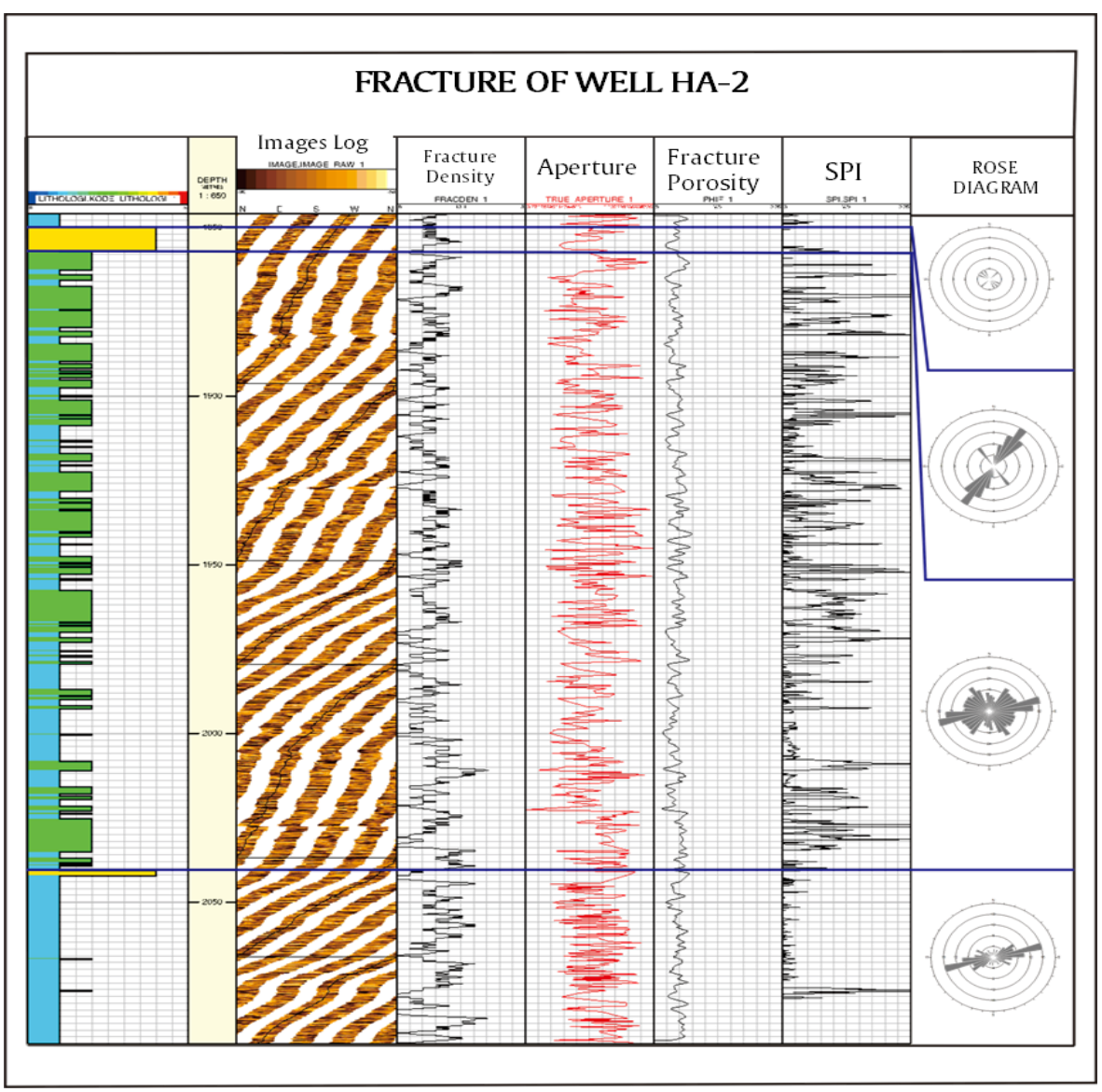

Fig. 8. Fracture from log images on well HA-1 


\section{Discussion}

Based on the calculation of fracture porosity $\mathrm{HA}-1$ has a bigger fracture porosity value than HA2. This indicates that well HA-1 has a better capability in storing fluid as compared to well HA2.The result matches with the test production data which specifies that HA-1 has better production than HA-2.Both of these wells are gas flow wells, which means both of them are producing gas. From the test, it is known that $\mathrm{HA}-1$ produces 4.2 MMSCFPD, while HA-2 produces 0.83 MMSCFPD. From the processing offracture, it was concluded that most of the fractures have northeast - south west (NE-SW) orientation. This shows us the possibility of the fractures being formed as a result of the main stress, which has an orientation of northwest - southwest (NW-SE) orientation in Sumatra Island.It was speculated that the formation of fracture system during the tensional phase Late Cretaceous - Early Tertiary produced normal fault and growth fault with $\mathrm{N}$ - S and WNW - ESE orientation respectively. Sedimentary process filled the basin above basement rock simultaneously with volcanic activity. The value of fracture porosity is deeply affected by the presence of fractures, otherwise known as fracture density.The analysis on both well HA-1 and well HA-2 showed different values with each interval. Thus, it can be concluded that the presence of fractures on the Pre-Tertiary basement rock formation is not affected much by the composing lithology.On a different note, the dominant factor that serves to control the fractures is the tectonic forces in the surrounding area. Based on the fractures on the basement rock, it was concluded that these fractures have northeast - southwest orientation. This matches the result of Jambi pattern geological structure which has similar orientation.As we already know, there are three structural patterns in the island of Sumatra, namely Jambi pattern, Sumatra pattern, and Sunda pattern. Out of these three patterns, the Jambi pattern is the one that plays the largest role in South Sumatra basin and Jambi sub-basin. Thus, it can be said that the presence of fractures on Jambi sub-basin's basement rock is controlled by Jambi pattern geological structure. The analysis of impact caused by the regional geology structure will play a part in determining potential areas which can be used as hydrocarbon reservoirs. By knowing the orientation of the fractures, we can predict the best direction of the drill when searching for a reservoir. With a fracture orientation of northeast southwest, it is recommended to drill with an orientation of northwest - southeast. In this way, we can get as much fractures as possible, thus increasing the chance of finding a reservoir.

\section{Conclusion}

Based on the analysis result and data processing in order to determine the characteristics of Basement Fracture Reservoir in
Pre-Tertiary Metasediment Basement on well HA1 and well HA-2, field X, South Sumatra Basin, it can be concluded that:

a. Basement of both wells are comprised of low grade metamorphic rocks such as slate, phyllite, quartzite, marble, and a thin layer of schist in well HA-2.

b. Petrography analysis shows the presence of fractures on basement formation rock.

c. Based on the fracture analysis as secondary porosity, the values of fracture porosity in both wells were obtained. Well HA-1 PHI has $1.49 \%$ fracture porosity value with an orientation of NE - SW relative to its fracture plane. Meanwhile, well HA-2 PHI has $0.888 \%$ fracture porosity value with an orientation of ENE - WSW relative to its fracture plane.

d. Based on fracture analysis, well HA-1 has a superior capability to store fluid as compared to well HA-2. This was validated by the test production data, which stipulates that well HA-1 has higher production than well HA-2.

e. The existing fractures are not affected much by physical and chemical properties of rock, although they are affected by tectonic forces in surrounding area. It was speculated that the fractures are affected by Jambi pattern which has an orientation of NE - SW.

\section{Acknowledment}

We would like to express our deepest gratitude to PT.FERG Geosains Indonesia for allowing us the chance to do research about Basement Fracture Reservoir. We would also like to extend our heart felt gratitude to Dipo Caesario, S.T., M,T. for his wisdom and guidance during our research.

\section{Reference}

Aguilera, R. 1995. Naturally Fractured Reservoir. Second Edition: Tusla, OK, PennWell

Asquith, G.B. 1976. Basic Well Log Analysis for Geologist. Edisi ke-2. American Association of Petroleum Geologist: Oklahoma.

Bishop, M. G. 2001. South Sumatera Basin Province, Indonesia: The Lahat/Talang Akar-Cenoic Total Petroleum system. United States Geological Survey Open-File Report 99-50-S.

De Coster G.L 1974. The Geologi of The Central and South Sumatera Back Arc Basin: Proceedings Indonesian Petroleum Association, 10th Annual Convention: Jakarta.

Diament, M., Harjono, H., Karta, K., Deplus, C., Dahrin, D., Zen, JR. M.T., Gerrard, M., Lassal, O., Martin, A. \& Malod, J. 1992. Mentawai Fault Zone off Sumatra : A New Key to the Geodynamics of Western Indonesia. Geology 20, 259-262.

Hamilton, W. 1979. Tectonics of the Indonesia Region. U.S.Geological Survey, Professional Paper. 1078,345 h.

Handayani, L., and Harjono, H. 2008. Perkembangan Tektonik Daerah Busur Muka 
Selat Sunda dan Hubungannya dengan Zona Sesar Sumatera. Jurnal Riset Geologi dan Pertambangan 18, 31-40.

Harsono, A. 1997. Evaluasi Formasi dan Aplikasi Log, Edisi 8. Schlumberger Oildfield Service: Jakarta.

Indonesian Basin Summaries. 2006. Patra Nusa Data: Jakarta.

Koesoemadinata, R.P.1980. Geologi Minyak dan Gas Bumi, Jilid 1 dan 2. Institut Teknologi Bandung: Bandung.

Landes, K.K et al. 1960. Petroleum Resources in Basement Rocks. AAPG Bulletin. 44, pp 16821691

Nelson, R. A. 2001. Geological Analysis of Naturally Fractured Reservoirs. Second Edition. Gulf Professional Publishing: USA.

Pulunggono, A. et al, 1992. Pre-Tertiary and Tertiary Fault System As a Framework of the South Sumatera Basin: A study of SAR-MAPS. Proceed. Indon. Petrol. Assoc. 21st Annual Conv. Pp 339-360.

Raymond, L. A.1943. Petrology, The Study of Igneous, Sedimentary, and Metamorphic Rocks. Second Edition. Appalachian State Universiy: Boston.

Rider, M. 1996. The Geological Interpretation of Well Log. Petroleum Exploration Consultant: Aberdeen.

Sen, G. 2001. Petrology, Principles and Practice. American University of Sharjah: Sharjah, United Arab Emirates.

Simandjuntak, T.O. 2015. Tektonika. Edisi ke-4. Badan Geologi Kementrian Energi dan Sumber Daya Mineral.

Syafri, I. 2002. Petrologi. Pusat Pendidikan dan Pelatihan Geologi: Bandung.

Zou, C. 2013. Unconventional Petroleum Geologiy. Research Institut of Petroleum Exploration \& Development: Beijing 